\title{
Optimization and partial purification of beta-galactosidase production by Aspergillus niger isolated from Brazilian soils using soybean residue
}

\author{
Raquel Dall'Agnol Martarello', Luana Cunha', Samuel Leite Cardoso', Marcela Medeiros de Freitas', \\ Damaris Silveira' ${ }^{1}$, Yris Maria Fonseca-Bazzo ${ }^{1}$, Mauricio Homem-de-Mello' ${ }^{1}$ Edivaldo Ximenes Ferreira Filho ${ }^{2}$ \\ and Pérola Oliveira Magalhães ${ }^{1 *}$ (1)
}

\begin{abstract}
$\beta$-Galactosidases are widely used for industrial applications. These enzymes could be used in reactions of lactose hydrolysis and transgalactosylation. The objective of this study was the production, purification, and characterization of an extracellular $\beta$-galactosidase from a filamentous fungus, Aspergillus niger. The enzyme production was optimized by a factorial design. Maximal $\beta$-galactosidase activity $(24.64 \mathrm{U} / \mathrm{mL})$ was found in the system containing $2 \%$ of a soybean residue $(\mathrm{w} / \mathrm{V})$ at initial $\mathrm{pH} 7.0,28^{\circ} \mathrm{C}, 120 \mathrm{rpm}$ in 7 days. ANOVA of the optimization study indicated that the response data on temperature and $\mathrm{pH}$ were significant $(\mathrm{p}<0.05)$. The regression equation indicated that the $\mathrm{R}^{2}$ is 0.973. Ultrafiltration at a 100 and $30 \mathrm{kDa}$ cutoff followed by gel filtration and anion exchange chromatography were carried out to purify the fungal $\beta$-galactosidase. SDS-PAGE revealed a protein with molecular weight of approximately $76 \mathrm{kDa}$. The partially purified enzyme showed an optimum temperature of $50^{\circ} \mathrm{C}$ and optimum pH of 5.0 , being stable under these conditions for $15 \mathrm{~h}$. The enzyme was exposed to conditions approaching gastric $\mathrm{pH}$ and in pepsin's presence, $80 \%$ of activity was preserved after $2 \mathrm{~h}$. These results reveal a A. niger $\beta$-galactosidase obtained from residue with favorable characteristics for food industries.
\end{abstract}

Keywords: Fungi, $\beta$-Galactosidase, Purification, Optimization, Agroindustrial residues

\section{Introduction}

Fermentation of agroindustrial residues received a great deal of attention in recent years. Many byproducts and raw materials from the food industry and agriculture, e.g., soybean residues, sugarcane bagasse, cotton stalk, corn cob, and mango peel have been used to produce biotechnological products owing to their high availability. They are also an alternative source of nutrients with low commercial cost (Moreira et al. 2012).

\footnotetext{
*Correspondence: perolamagalhaes@unb.br

${ }^{1}$ Laboratory of Natural Products, Health Sciences School, Department of Pharmaceutical Sciences, University of Brasília, Brasília, DF CEP 7910-900, Brazil

Full list of author information is available at the end of the article
}

The agroindustrial residues are mainly composed of lignocellulosic material. Considering that $90 \%$ of agroindustrial residues are discarded into the environment, the use of these residues as raw materials should reduce environmental pollution and may also increase the economic value of the residues (Moreira et al. 2012).

Brazil is the second biggest producer of soybeans (Glycine $\max$ ) worldwide. In the 2014-2015 harvest, soybean planting area reached 30.1 million hectares, producing a crop of 95 million tons of soybeans (Embrapa 2016). One application for soybean byproducts is fermentation by microorganisms including bacteria and fungi that are able to degrade the lignocellulosic material of the agricultural residues. These residues could be utilized by filamentous fungi as a carbon source for the production 
of enzymes, in particular hydrolytic ones (Moreira et al. 2012). Aspergillus fungi have been chosen for large-scale processes because they can produce large quantities and varieties of enzymes in a low-cost medium (Bergquist et al. 2002). Moreira et al. (2012) studied the degradation of lignocellulosic residues for production of enzymes of industrial significance such as xylanases, mannanases, pectinases, $\beta$-glucosidases, avicelases, phosphatases, and carboxymethyl cellulases by different species of fungi isolated from soil, including Aspergillusterreus, Aspergillusoryzae, and Aspergillusniger (Moreira et al. 2012).

A large number of microorganisms have been assessed as potential sources of $\beta$-D-galactosidase ( $\beta$-D-galactoside galactohydrolase, EC 3.2.1.23, most commonly known as lactase) to hydrolyze lactose into glucose and galactose for lactose-free milk production and products intended for lactose-intolerant consumers (Isobe et al. 2013a). Traditionally, the $\beta$-galactosidases most widely used in industry were obtained from Aspergillus spp. and Kluyveromyces spp. (Panesar et al. 2006), because these could be readily obtained with acceptable productivities and yields from cultivations of these microorganisms. Additionally, products obtained from these organisms are generally recognized as safe (GRAS status) for human consumption, which is critical for food related applications (Panesar et al. 2006). In Aspergillus niger the $\beta$-galactosidase enzymes are secreted to the extracellular medium, increasing the interest in finding new culture source for the production of this enzyme (Panesar et al. 2006). Besides, lactose is a hygroscopic sugar that has low solubility; it could induce crystallization and may cause technological problems for certain products in the dairy industry. The solubility and sweetness can be increased by the lactose hydrolysis. Many problems in refrigerated foods such as crystallization in dairy foods, precipitate formation in frozen foods, and development of a gritty texture may be reduced with lactose hydrolysis (Klein et al. 2010; Panesar et al. 2006).

$\beta$-Galactosidases also participate in the synthesis of galactooligosaccharides (GOSs) and can be applied to functional foods such a slow-calorie foods or as an additive in fermented dairy products, breads, and drinks.

Moreover, in the pharmaceutical industry, $\beta$-galactosidase is produced as a food supplement for lactose-intolerant people. Many symptoms of lactose intolerance are minimized by the use of exogenous $\beta$ galactosidase before ingestion of milk or dairy products (O'Connell and Walsh 2008; Oliveira et al. 2011).

Optimization of the fermentation process can reduce the production costs for $\beta$-galactosidase and is important for enabling an industrial application and to obtain "green processes." For this reason, the selection of a low-cost culture is fundamental (Liu et al. 2007). Optimization of media components by the traditional "one-variable-at-atime" strategy is time-consuming and expensive when a large number of variables are considered. This method is incapable of detecting the true optimum, especially because of the interactions between the factors (Haji et al. 2008). Recently, a number of statistical designs were successfully employed for optimization of enzyme production by microorganisms. Response surface methodology (RSM) is one of the most popular optimization procedures, developed mainly from the factorial central composite design (CCD). Furthermore, CCD minimizes the risk of losing a nonlinear relation between intervals and enables researchers to estimate a reasonable model and check the fit of the model. These statistical techniques have been successfully applied in many studies for optimization of a culture medium (Patel et al. 2005). These techniques are available using analysis of variance (ANOVA), which aims to reveal how much of total variance exists between and within the groups evaluated. If most of the variance is between the groups, then there is probably a significant effect. However, if most of the variance is within the values of the same group, there is probably no significant effect. The RSM could be used after ANOVA to correlate the effect of independent variables (Rodrigues and Iemma 2005). The objective of this study was to apply experimental models to increase galactosidase production followed by purification with chromatographic and non-chromatographic methods and then enzymatic characterization.

The industrial search for alternative technologies that have high productivity, consume less resources, and have a lesser environmental impact is intensifying worldwide (Jegannathan and Nielsen 2013). Thus, the search for new fungal $\beta$-galactosidase sources produced from a soybean residue with industrial applicability is becoming interesting from biotechnological, economic, and environmental points of view.

\section{Materials and methods Chemicals}

The chemicals ONPG (o-nitrophenol- $\beta$-Dgalactopyranoside), $o$-nitrophenol, and other reagents were purchased from Sigma-Aldrich Chemical Co. (St. Louis, MO, USA). The media components used in this study were the following: peptone from Merck (Darmstadt, Germany), and potato dextrose agar (PDA) and yeast extract from HiMedia Laboratories Pvt. Ltd. (Mumbai, India).

\section{Residue pretreatment}

The soybean residue was autoclaved at $121{ }^{\circ} \mathrm{C}$ for $2 \mathrm{~h}$ and thoroughly washed with tap water. After that, it was dried at $65^{\circ} \mathrm{C}$ for $48 \mathrm{~h}$ and then ground into a relatively 
homogeneous blend. A fine powder was obtained and utilized as the carbon source. To obtain a liquid extract of soybeans (soymilk) and okara, $250 \mathrm{~g}$ of whole soybeans were washed and soaked in tap water for $12 \mathrm{~h}$; this step is called maceration. At the next step, the soybeans were washed again and cooked for $10 \mathrm{~min}$ in $1 \mathrm{~L}$ of boiling water. After that, the soybeans were washed with running water, passed through a mesh and ground for $3 \mathrm{~min}$ in $1 \mathrm{~L}$ of boiling water. Next, the ground beans were filtered through a cotton cloth strainer. The filtered liquid was the soy extract (soymilk), and the solid residue is called okara. The residue was then dried at $65{ }^{\circ} \mathrm{C}$ to suitable humidity of approximately $3-5 \%$, macerated, and stored at room temperature. The liquid extract was stored at $-20{ }^{\circ} \mathrm{C}$ until use.

\section{The microorganism and culture conditions}

Aspergillus niger strain was isolated from soil samples of the Brazilian biome Cerrado and deposited under strain code DCFS11 in the fungal culture collection at the Enzymology Laboratory, University of Brasilia, Brazil (genetic heritage number 010237/2015-1). The strain was also deposited in the bank of microorganisms for control of plant pathogens and weeds of the Brazilian Agricultural Research Corporation (EMBRAPA). The collection is registered at the World Data Centre for Microorganisms (WDCM), under the code MCPPW 1128. It was preserved in $0.9 \% \mathrm{NaCl}(\mathrm{w} / \mathrm{v}), 50 \%$ glycerol $(\mathrm{v} / \mathrm{v})$, and $0.01 \%$ Tween $80(\mathrm{v} / \mathrm{v})$ solution at $-80^{\circ} \mathrm{C}$ and propagated on potato dextrose agar plates at $28^{\circ} \mathrm{C}$. The isolate was initially subjected to morphological identification according to Silva et al. (2018). The internal transcribed spacer region (ITS) and genes for $\beta$-tubulin (BT) and calmodulin (CMD) were used as molecular markers to confirm fungal identity (Silva et al. 2018).

\section{Enzyme production}

Initial screening for the most significant carbon source was performed via the one-variable-at-a-time approach. The carbon sources included soybean residue, okara, and soymilk $(2 \%, \mathrm{w} / \mathrm{v})$ and were supplemented with $0.4 \%$ of peptone, $0.4 \%$ of yeast extract, $0.2 \%$ of $\mathrm{KH}_{2} \mathrm{PO}_{4}, 0.8 \%$ of $\mathrm{NaH}_{2} \mathrm{PO}_{4}$, and $0.25 \% \mathrm{MgSO}_{4}$ at initial $\mathrm{pH}$ 7.0. Cultures were inoculated with $10^{7}$ spores $/ \mathrm{mL}$ in $250 \mathrm{~mL}$ Erlenmeyer flasks with a working volume of $50 \mathrm{~mL}$ of culture media and were incubated on a rotatory shaker (120 rpm) at $28^{\circ} \mathrm{C}$ for 7 days. The culture medium and mycelia were harvested by vacuum filtration through Whatman No. 1 filter paper on a Büchner funnel. The obtained supernatant was utilized for crude extract preparation.
Table 1 Variables values of a $2^{3}$ factorial design with centered face and three repetitions at the central point used to evaluate the influence of $\left(X_{1}\right)$ speed agitation, $\left(X_{2}\right)$ temperature and $\left(X_{3}\right) \mathrm{pH}$ on $\beta$-galactosidase production

\begin{tabular}{llrrr}
\hline Variables & Symbol code & \multicolumn{2}{l}{ Levels } & \\
\cline { 3 - 5 } & & \multicolumn{1}{c}{$\mathbf{1}$} & \multicolumn{1}{c}{$\mathbf{0}$} & $\mathbf{1}$ \\
\hline Speed agitation (rpm) & $X_{1}$ & 100 & 120 & 140 \\
Temperature $\left({ }^{\circ} \mathrm{C}\right)$ & $X_{2}$ & 22 & 28 & 34 \\
$\mathrm{pH}$ & $X_{3}$ & 5 & 7 & 9 \\
\hline
\end{tabular}

\section{Enzymatic assay}

$\beta$-Galactosidase activity was determined by the method proposed by Nagy et al. (2001). The crude extract $(0.05 \mathrm{~mL})$ was mixed with $0.05 \mathrm{~mL}$ of $3 \mathrm{mM} o$-nitrophenol- $\beta$-Dgalactopyranoside (ONPG) dissolved in $0.1 \mathrm{M}$ sodium phosphate buffer ( $\mathrm{pH} 7.0$ ), and incubated at $30{ }^{\circ} \mathrm{C}$ for $30 \mathrm{~min}$. The reaction was stopped by adding $2.0 \mathrm{~mL}$ of a $0.1 \mathrm{M}$ sodium carbonate solution $\left(\mathrm{Na}_{2} \mathrm{CO}_{3}\right)$. One unit $(\mathrm{U})$ of $\beta$-galactosidase activity was defined as the amount of the enzyme catalyzing the release of $1 \mu \mathrm{mol}$ of $o$-nitrophenol per min according to measurement of absorbance at $410 \mathrm{~nm}$. Protein concentration was measured by the Bradford method (Bradford 1976), with bovine serum albumin as a standard.

\section{The experimental design}

To characterize how the significant factors, affect the responses, we attempted to improve composition of the medium by comparing different levels of several factors that were found to have more influence on the $\beta$-galactosidase production. According to the results of the one-variable-at-a-time experiments, the effects of three factors, agitation speed $\left(X_{1}\right)$, temperature $\left(X_{2}\right)$, and $\mathrm{pH}\left(X_{3}\right)$, were found to be the major variables affecting enzyme production in the medium containing the soybean residue. For this purpose, RSM involving a central composite design (CCD) was employed for optimization of the enzyme production. In this regard, a set of 11 experiments, including $2^{3}$ factorial experiments with three center points, were carried out. Each variable was studied at two different levels $(-1$, +1 ) and at a center point $(0)$, which is the midpoint of each factor range (Table 1 ). The response values $(Y)$ in each trial were averages of triplicates.

The experimental results of RSM were fitted via the response surface regression procedure, by means of the following second-order polynomial equation:

$$
Y=\alpha_{0}+\sum_{i} \alpha_{i} X_{i}+\sum_{i j} \alpha_{i j} X_{i} X_{j}
$$


where $Y$ is the predicted response; $\alpha_{0}$ is an intercept term; $\alpha_{i}$ is a linear coefficient; $\alpha_{i i}$ is a quadratic coefficient; and $\alpha_{i j}$ are interaction coefficients. $X_{i}$ and $X_{j}$ are the levels of the independent variables.

A statistical software package, Statistica 7.0, was used for the regression analysis of the experimental data and to plot the response surface graphs. Only the factors with significance higher than or equal to $95 \%(p<0.05)$ were considered. The quality of fit of the second-order polynomial model equation was expressed via the coefficient of determination $\left(R^{2}\right)$ and adjusted $R^{2}$. The fitted polynomial equation was then expressed in the form of three-dimensional surface plots, to illustrate the correlation between the responses and the experimental levels of each variable utilized in this study. The point optimization method was employed to optimize the level of each variable for a maximum response. The combination of different optimized variables that yielded a maximum response was determined in an attempt to validate the model.

\section{Enzyme purification}

The $A$. niger culture was filtered, and the supernatant was ultrafiltered through membranes with a 100 and $30 \mathrm{kDa}$ cutoff. Subsequent assays were conducted on a purification system (AKTA PURE; GE Healthcare). The obtained enzyme solution was eluted on a Sephacryl S-200 column $(16 \times 60 \mathrm{~cm})$ equilibrated with $0.1 \mathrm{M}$ sodium phosphate buffer, $\mathrm{pH}$ 7.0. The sample eluted at a fixed flow rate of $0.5 \mathrm{~mL} / \mathrm{min}$ was collected in $2 \mathrm{~mL}$ fractions. Fractions with $\beta$-galactosidase activity were pooled and lyophilized.

The lyophilized sample from the gel filtration column was dissolved in 0.1 M sodium phosphate buffer, $\mathrm{pH}$ 7.0. The sample was passed through a DEAE Fast Flow anion exchange column (DEAE FF-GE Healthcare; $1 \mathrm{~mL}$ ) equilibrated with the same buffer at a flow rate of $0.25 \mathrm{~mL} /$ min. A linear gradient of sodium chloride $(0.0$ to $1 \mathrm{M})$ was applied.

\section{Enzyme characterization Electrophoresis (SDS-PAGE) and a zymogram}

The protein profile of the denatured samples was analyzed in a $10 \%$ polyacrylamide gel stained with a Coomassie blue solution. For the zymogram, the gel obtained by the electrophoretic run of a nondenatured sample was immediately incubated in a buffer consisting of a solution of 5-bromo-4-chloro-indolyl- $\beta$-D-galactopyranoside $(\mathrm{X}-\mathrm{Gal})$ at $0.02 \%(\mathrm{w} / \mathrm{v})$ (O'Connell and Walsh 2008).

\section{Effects of $\mathrm{pH}$ and temperature on enzymatic activity}

The $\mathrm{pH}$ effect on $\beta$-galactosidase activity was estimated in the presence of buffer solutions: potassium chloridehydrochloric acid (pH 1.0 to 1.5 ), $50 \mathrm{mM}$ sodium acetate $(\mathrm{pH} 2.0$ to 6.0$)$, and $50 \mathrm{mM}$ sodium phosphate $(\mathrm{pH}$
7.0 to 9.0 ) and the activity was measured as described above (Enzymatic assay). The optimal temperature of the enzyme was evaluated at $4{ }^{\circ} \mathrm{C}, 10{ }^{\circ} \mathrm{C}, 15^{\circ} \mathrm{C}, 20^{\circ} \mathrm{C}, 30{ }^{\circ} \mathrm{C}$, $40{ }^{\circ} \mathrm{C}, 50{ }^{\circ} \mathrm{C}, 60^{\circ} \mathrm{C}, 70{ }^{\circ} \mathrm{C}$, and $80^{\circ} \mathrm{C}$. Enzymatic activity was assessed as described above (Enzymatic assay).

\section{Thermostability}

The samples were incubated at $50{ }^{\circ} \mathrm{C}$ for $20 \mathrm{~h}$. The assay was performed at $\mathrm{pH}$ 3.0. The residual enzymatic activity was determined every $60 \mathrm{~min}$, as in the enzymatic assay described above (Enzymatic assay).

\section{Stability under gastric conditions}

Simulation of gastric digestion was conducted by a modified method of O'Connell and Walsh (2008). We incubated $5 \mathrm{~mL}$ of the enzyme with $5 \mathrm{~mL}$ of simulated gastric fluid (SGF), pH 2.0 for $2 \mathrm{~h}$ at $37^{\circ} \mathrm{C}$ and $150 \mathrm{rpm}$. The SGF was prepared as per Brazilian Pharmacopoeia and consisted of a solution containing $0.2 \%$ of $\mathrm{NaCl}, 0.32 \%$ of purified bovine pepsin (Sigma-Aldrich, USA), and 7.0\% $\mathrm{HCl}$. A control composed of the buffer and enzyme and another control consisting of the buffer and SGF were set up too.

\section{Determination of the kinetic parameters of $\beta$-galactosidase}

The Michaelis-Menten constant $\left(\mathrm{K}_{\mathrm{m}}\right)$ and tests for maximum velocity $\left(\mathrm{V}_{\max }\right)$ determination were performed at substrate concentrations (ONPG) ranging from 1 to $50 \mathrm{mM}$, and the substrate lactose concentrations ranging from 1 to $300 \mathrm{mM}$. Activity assays were performed as described above by replacing the ONPG with the substrates at the concentrations mentioned above. The results on the kinetic parameters were obtained in the Enzfitter software (Leatherbarrow 1999).

\section{Results \\ The effect of the soybean residue on $\beta$-galactosidase production}

The $A$. niger strain was grown in a liquid medium supplemented with the soybean residue, okara, or soymilk for 7 days. The highest activity was observed in the medium with the soybean residue when compared with okara and soymilk, as shown in Fig. 1. Considering its low $\beta$-galactosidase activity, the growth in soymilk medium was rejected from this study.

Among the residues tested as carbon sources, the soybean residue was the most suitable substrate for $\beta$-galactosidase production. Thus, this substrate was selected for further optimization steps.

\section{Evaluation of $\beta$-galactosidase production}

In the present study, CCD was implemented along with the corresponding results of RSM experiments to 


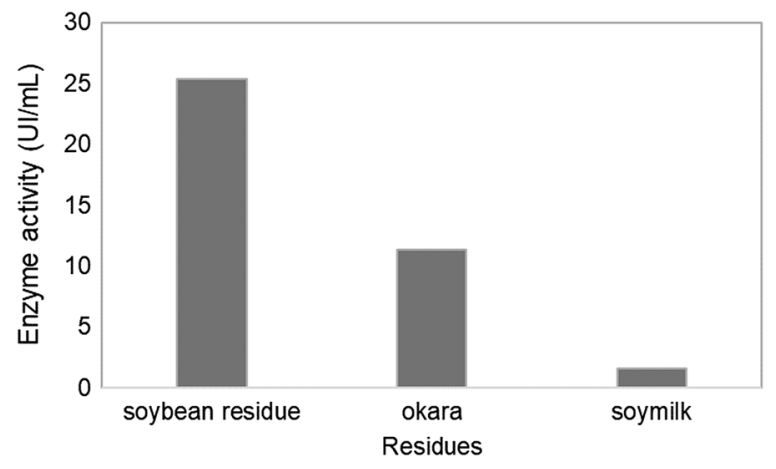

Fig. $1 \beta$-galactosidase activity in different soybean products, after 7 days of submerse fermentation at $120 \mathrm{rpm}$ and $28^{\circ} \mathrm{C}$
Table 3 Analysis of variance (ANOVA) for $\beta$-galactosidase activity

\begin{tabular}{lcl}
\hline Source & $\boldsymbol{F}$ value & $\boldsymbol{p}$-value $\boldsymbol{F}$ \\
\hline Model & 18.21 & 0.018 \\
Speed agitation & 1.92 & 0.259 \\
Temperature & 32.17 & 0.010 \\
$\mathrm{pH}$ & 60.04 & 0.004 \\
$X_{1} X_{2}$ & 5.83 & 0.094 \\
$X_{1} X_{3}$ & 3.22 & 0.170 \\
$X_{2} X_{3}$ & 6.07 & 0.090 \\
Lack of fit & 9.110 & 0.094 \\
\hline
\end{tabular}

The model including as independent variables $(\mathrm{X} 1)$ agitation, $(\mathrm{X} 2)$ temperature and (X3) pH

$\beta$-galactosidase activity to a considerable extent. Therefore, the regression equation coefficients were calculated in terms of actual factors. The data were fitted to a second-order polynomial equation, and the response $(Y)$, i.e., $\beta$-galactosidase production by $A$. niger, could be expressed as follows: where $X_{1}, X_{2}$, and $X_{3}$ are agitation speed, temperature, and $\mathrm{pH}$, respectively.

The regression equation obtained by ANOVA (Table 3) indicated that the multiple correlation coefficient $R^{2}$ is 0.973 (value greater than 0.75 indicates suitability of the model), i.e., the model can explain 97.3\% of the variation response. The $F$ value of the model was 18.21 , implying that the model is significant. The $P$ values for the model $(0.018)$ and for a lack of fit $(0.0945)$ suggested that the data were a good fit for the model. The ANOVA provided a satisfactory adjustment of the model to the experimental data. The results indicated that the model could be used to predict the $\beta$-galactosidase activity.

The speed of agitation has no statistically significant influence on $\beta$-galactosidase production. On the other hand, $\mathrm{pH}$ and temperature, among the analyzed factors, interfere with enzymatic activity. The temperature and $\mathrm{pH}$ have a negative influence on $\beta$-galactosidase activity. The predicted negative sign (-) of variables $X_{1}$ and $\mathrm{X}_{3}$ indicated that an increase in temperature or $\mathrm{pH}$ tended to reduce $\beta$-galactosidase activity and the interactions among variables $X_{1}, X_{3}, X_{1} X_{2}$, and $X_{2} X_{3}$ were not significant.

To determine the optimal levels of each variable for maximal $\beta$-galactosidase production by $A$. niger, threedimensional response surface graphs were constructed by plotting the response (enzyme production) on the $z$-axis against two independent variables, while maintaining other variables at their optimal levels. The Fig. 2 shows the effects of temperature and $\mathrm{pH}$ on $\beta$-galactosidase production in a medium containing the soybean residue. factor, and even small variations in its value will alter 


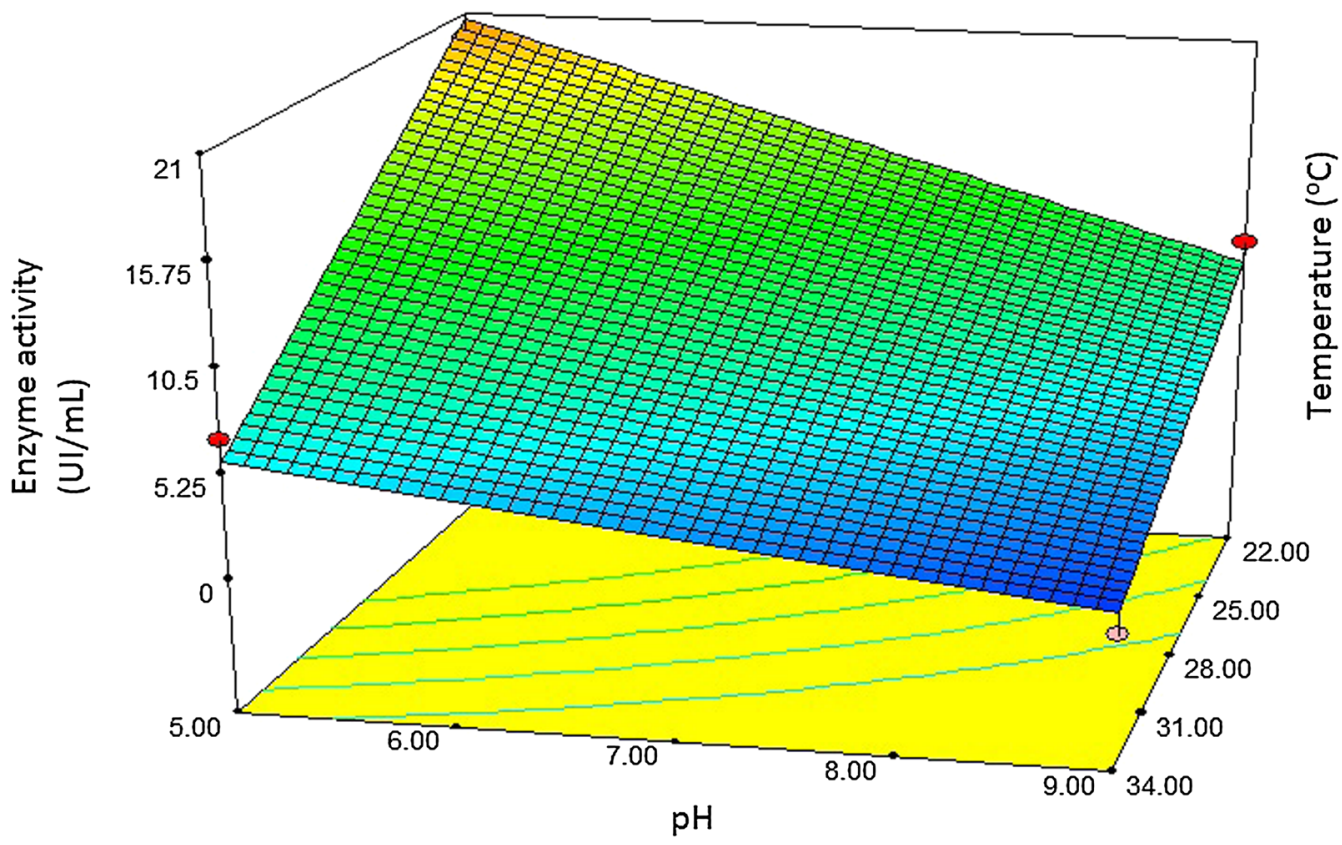

Fig. 2 Response surface curve of $\beta$-galactosidase activity affected by temperature and pH using the 2 -factor central composite design

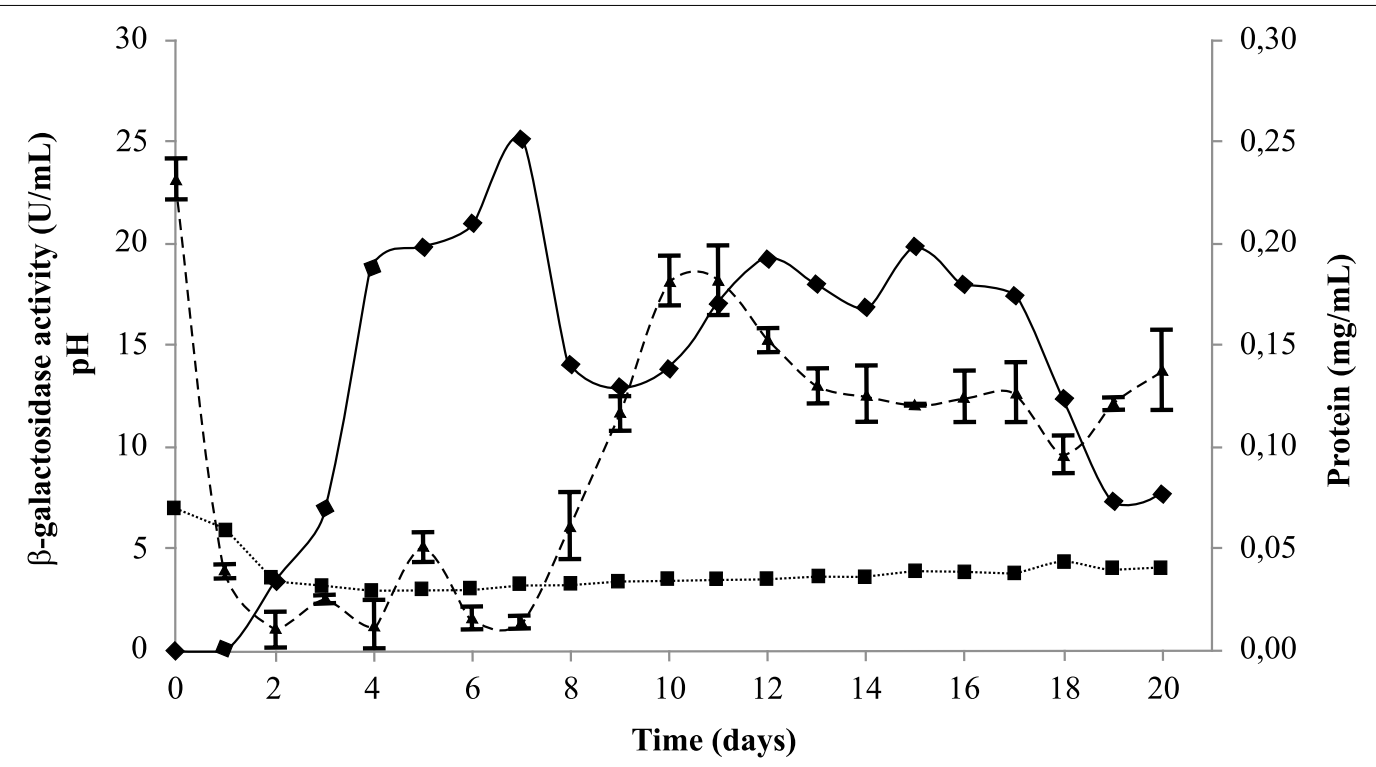

Fig. 3 Time courses of $\beta$-galactosidase production by Aspergillus niger under optimized conditions $\left(120 \mathrm{rpm}, 28^{\circ} \mathrm{C}\right.$, initial medium pH 7), using medium supplemented with $2 \%$ of soybean residue. Medium pH (...), protein $(\mathrm{mg} / \mathrm{mL})(---)$ and $\beta$-galactosidase activity $(-)$

\section{Construction of the growth curve for $A$. niger reflecting}

\section{$\beta$-galactosidase activity}

The growth curve of the $\beta$-galactosidase production by $A$. niger under the best conditions obtained by RSM was constructed after monitoring the data for 20 days. As presented in Fig. 3, after 4 days of fermentation, the production of $\beta$-galactosidase increased dramatically. This production reached a maximum $(25.11 \mathrm{U} / \mathrm{mL})$ after 7 days of fermentation in the medium supplemented with the soybean residue.

The amount of protein changed during the culture period, suggesting that this result may include other 
Table 4 Summary of purification steps of $\beta$-galactosidase from $A$. niger

\begin{tabular}{|c|c|c|c|c|c|}
\hline Purification steps & Protein $(\mathrm{mg} / \mathrm{mL})$ & Activity (UI/mL) & $\begin{array}{l}\text { Specific activity (UI/ } \\
\text { mg) }\end{array}$ & Yield (\%) & $\begin{array}{l}\text { Purification } \\
\text { (fold) }\end{array}$ \\
\hline Crude & 0.150 & 26.000 & 173.333 & 100.000 & 1.000 \\
\hline$<100$ & 0.144 & 24.000 & 166.667 & 92.308 & 0.962 \\
\hline$>30$ & 0.065 & 23.440 & 360.615 & 90.154 & 2.080 \\
\hline S-200 & 0.0075 & 6.570 & 876.000 & 25.269 & 5.054 \\
\hline DEAE & 0.003 & 4.506 & 1502.000 & 17.331 & 8.665 \\
\hline
\end{tabular}

Table 5 Substrate specificity of $\boldsymbol{\beta}$-galactosidase partially purified from Aspergillus niger

\begin{tabular}{lc}
\hline Substrate $^{\mathbf{a}}$ & ${\text { Activity }(\mathbf{U I} / \mathbf{m L})^{\mathbf{b}}}$ \\
\hline ONPG & $22.125 \pm 0.018$ \\
Lactose & $5.622 \pm 0.002$ \\
CM-cellulose & $0.253 \pm 0.004$ \\
PNPG & $0.043 \pm 0.005$
\end{tabular}

a ONPG: o-nitrophenol- $\beta$-D-galactopyranoside; $\rho N P G$ : $\rho$-nitrophenol- $\beta$-Dgalactopyranoside; $C M$-cellulose: carboxymethyl celulose; Lactose: $\beta$-Dgalactopyranosyl-( $1 \rightarrow 4)$-D-glucose

b One unit (U) of $\beta$-galactosidase activity was defined as the amount of the enzyme catalyzing the release of $1 \mu \mathrm{mol}$ of $o$-nitrophenol per min at $410 \mathrm{~nm}$ (Nagy et al. 2001)

enzymes besides $\beta$-galactosidase, which are simultaneously produced and participate in the substrate degradation process. The induction profile followed $\mathrm{pH}$ variation, with a maximum value of 5.92 on the 1st day of culture and minimum value of 2.94 on the 4 th day.

\section{$\beta$-Galactosidase purification}

The crude extract was concentrated approximately 2 -fold at $4{ }^{\circ} \mathrm{C}$ by ultrafiltration on an Amicon membrane System (Amicon Inc., Beverly, MA, USA) with a 100 and $30 \mathrm{kDa}$ cutoff (Table 4).

The concentrated fraction $(>30)$ was eluted from an S-200 chromatographic column and yielded only one $\beta$-galactosidase activity peak 1 S-200. Peak 1 S-200 was eluted from an anionic ion exchange column (HiTrap DEAE-FF $1 \mathrm{~mL}$ ) resulting in two activity peaks. The first one ( $\beta$-gal peak) showed the highest activity $(1502 \mathrm{UI} / \mathrm{mg}$ protein) and was selected for the following tests. The final purification factor with two chromatographic steps was 8.665 and the yield was $17.33 \%$ (Table 5).

The protein profiles of each step of $A$. niger $\beta$-galactosidase purification were followed by electrophoresis. The Fig. 4 shows an electrophoretic run of S-200 (2) and DEAE (3).

In fraction (2), only two bands were observed with estimated molar masses of 76.58 and $70.25 \mathrm{kDa}$. Fraction (2) refers to a single activity peak present in the chromatogram ( $\beta$-gal peak; Fig. 4$)$, suggesting that in the partially purified fraction, there are two proteins with very close molecular weight and similar physical and chemical characteristics. Therefore, it was concluded that the column was not able to separate these two proteins. On the other hand, when we analyzed the zymogram (Fig. 4), there was a single blue band characteristic of $\beta$-galactosidase activity in X-Gal (Kishore and Kayastha 2012).

\section{Enzymatic characterization \\ Effects of temperature and $\mathrm{pH}$ on enzymatic activity}

$\beta$-Gal showed a higher activity between $\mathrm{pH} 2.0$ and 5.0, being more active at $\mathrm{pH} 3.0$ (Fig. $5 \mathrm{a}$ ). This enzyme needs to be active in acid $\mathrm{pH}$ values during lactose digestion, since gastric $\mathrm{pH}$ is known to be $1.5-2.5$. Acidic $\beta$-galactosidases are important for biotechnology with applications in the whey processing and yogurts. In addition, there is a high probability of resistance to gastric conditions enabling its use as food supplements for the lactose-intolerant population (O'Connell and Walsh 2008).

The influence of temperature on the $\beta$-gal activity is presented in Fig. 5b. The activity remained constant between $20{ }^{\circ} \mathrm{C}$ and $60{ }^{\circ} \mathrm{C}$, indicating the industrial applicability of this enzyme (O’Connell and Walsh 2008).

\section{Thermal stability}

Our aim is application of this enzyme to food products such as milk and derivatives. It is interesting from the industrial point of view that the enzyme is stable both at low temperatures (preventing proliferation of microorganisms and preserving nutrients in milk) and at high temperatures (pasteurization). Thus, the stability of the enzyme persisted at temperatures of $4{ }^{\circ} \mathrm{C}, 50{ }^{\circ} \mathrm{C}$, and $70{ }^{\circ} \mathrm{C}$ as depicted in Fig. $5 \mathrm{c}$.

The partially purified enzyme was subjected to a thermostability assay in which residual $\beta$-galactosidase activity was measured after an incubation period. After $1 \mathrm{~h}$ incubation at $70{ }^{\circ} \mathrm{C}$, there was no more enzymatic 
a

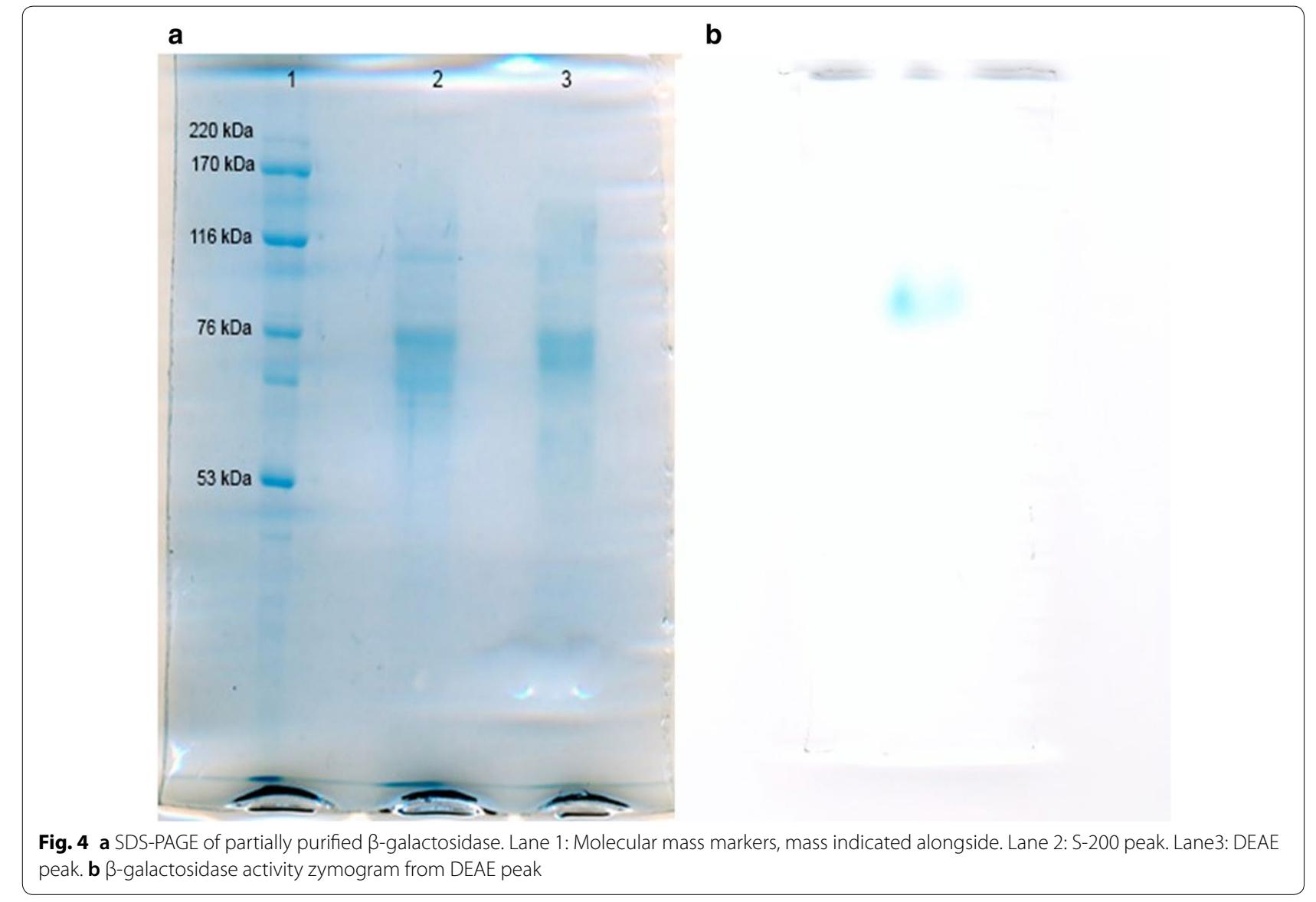

b activity, but when incubated at $50{ }^{\circ} \mathrm{C}$ for $1 \mathrm{~h}$, the enzymatic activity decreased by $33.3 \%$ and persisted for approximately $15 \mathrm{~h}$. When incubated at $4{ }^{\circ} \mathrm{C}$, the enzymatic activity persisted, indicating good stability at this temperature, which shows the possibility of the use in lactose hydrolysis in low temperatures.

\section{Substrate specificity and kinetic constants}

Specificity of the enzyme was evaluated by a hydrolysis assay involving several substrates (Table 4). The enzyme was active in the hydrolysis of ONPG and lactose. Toward the other substrates, the enzyme showed little or no activity.

The $\beta$-galactosidase showed activity mostly toward ONPG and lactose, indicating that the enzyme holds great promise for application in the dairy industry, which requires enzymes without action on other substrates.

In addition to specificity, the kinetic parameters $\left(\mathrm{K}_{\mathrm{m}}\right.$ and $\left.\mathrm{V}_{\max }\right)$ of $\beta$-galactosidase at $50{ }^{\circ} \mathrm{C}$ for the substrates ONPG and lactose were analyzed according to the Michaelis-Menten model. $\mathrm{K}_{\mathrm{m}}$ and $\mathrm{V}_{\max }$ for ONPG counts were $1.84 \mathrm{mM}$ and $256.65 \mathrm{IU} / \mathrm{mL}$, respectively, whereas for lactose, $\mathrm{K}_{\mathrm{m}}$ was $40 \mathrm{mM}$ and $\mathrm{V}_{\max } 2.86 \mathrm{IU} /$ $\mathrm{mL}$.

\section{Stability under simulated gastric conditions}

Because of possible industrial applicability of $\beta$-galactosidase as a digestive supplement for lactoseintolerant individuals, evaluation of the enzyme activity was performed under simulated gastric conditions. The enzymatic activity is presented as a percentage (\%) relative to the activity of the control, where $100 \%$ is equated to $0.5 \mathrm{IU} / \mathrm{mL}$. Figure 6 shows that $\beta$-galactosidase had a residual activity of $80 \%$ when subjected to SGF for $2 \mathrm{~h}$.

\section{Discussion}

$\beta$-Galactosidase production

Soybean agroindustrial residues are important for the biotechnology industry as an abundant low-cost source for enzymatic production. The use of soybean residues reduces environmental pollution. For this reason, this study evaluates the production of $\beta$-galactosidases by $A$. niger from soybean residues as a substrate.

Several $\beta$-galactosidases secreted by the fungus Aspergillus niger have been purified and characterized. The 


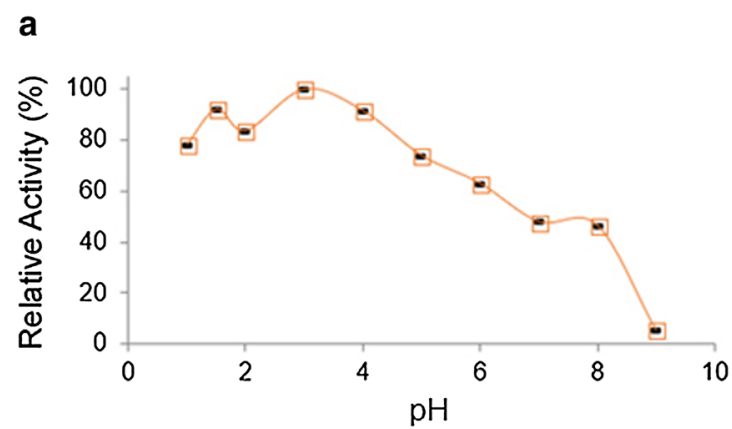

$\square$ Enzyme partially purified

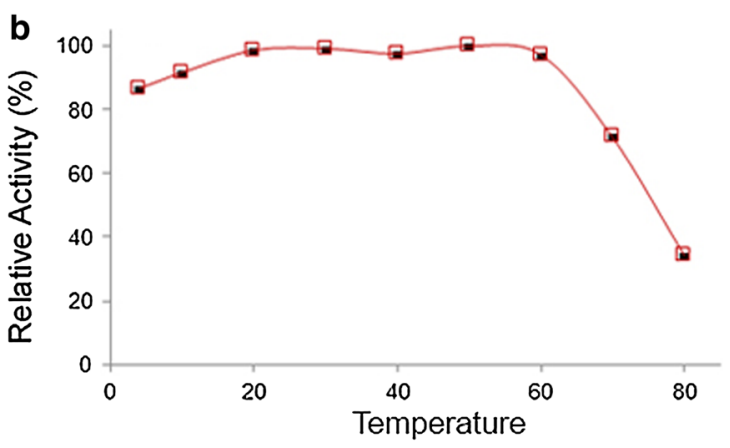

$\rightarrow$ Enzyme partially purified

C

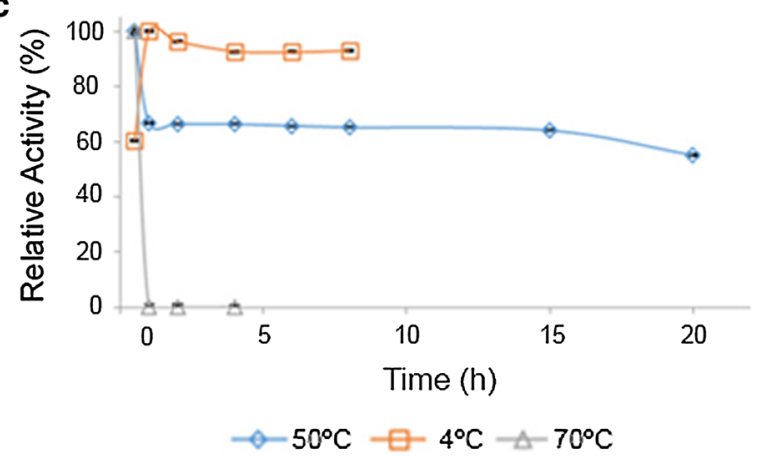

Fig. 5 a Activity versus pH profiles of the partially purified $\beta$-galactosidase. Enzyme activity is plotted as a \% value relative to the activity displayed at the enzyme's optimum $\mathrm{pH}$. Error bars indicate the standard deviation of the measured data values from the mean, $n=3$. $\mathbf{b}$ Activity versus temperature profiles of the partially purified $\beta$-galactosidase. Enzyme activity is plotted as a \% value relative to the activity displayed at the enzyme's optimum temperature. Error bars indicate the standard deviation of the measured data values from the mean, $\mathrm{n}=3$. $\mathbf{c}$ Temperature stability of the $\beta$-galactosidase partially purified from A. niger at $4{ }^{\circ} \mathrm{C}, 50^{\circ} \mathrm{C}$ and $70^{\circ} \mathrm{C}$

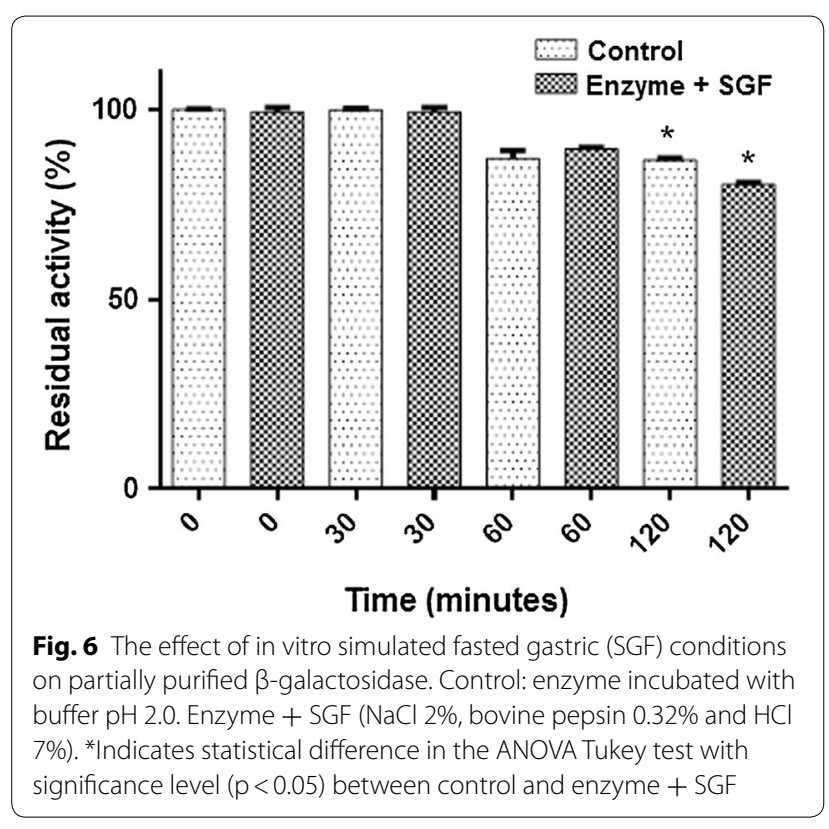

occurrence of this enzyme in multiple molecular forms has been suggested by previous work (O'Connell and Walsh 2008; $\mathrm{Hu}$ et al. 2010). Studies have shown that other microorganisms can express enzymes when cultivated with organic residues such as soybean residues (de Siqueira et al. 2010).

O'Connell and Walsh (2008) reported that $0.91 \mathrm{U} / \mathrm{mL}$ $\beta$-galactosidase activity is produced by Aspergillus carbonarius cultivated in wheat bran (O'Connell and Walsh 2008). In other study, $A$. niger grown with the soybean residue yielded $\beta$-galactosidase activity $60 \%$ greater than $\operatorname{did} A$. niger grown with the okara residue (O'Toole 1999). A decrease in enzymatic production in the okara residue medium can be attributed to the presence of phytic acid. The chelating ability of phytic acid present in okara prevents the use of micronutrients present in the culture medium. This chelating agent can scavenger minerals such as zinc, calcium, and iron, among others, by binding these metals, thereby making them insoluble and difficult to absorb by the fungus (O'Toole 1999).

RSM can be implemented to examine the relation between experimental factors and the observed results; furthermore, it is the most widely accepted statistical 
technique for bioprocess optimization. At the end of the screening experiments for different carbon sources, three factors (agitation speed, temperature, and medium $\mathrm{pH}$ ) were believed to play a significant role in $\beta$-galactosidase production and were selected for RSM.

According to Rahman et al. (2005), temperature also affects the synthesis of extracellular enzymes by causing changes in physical properties of the cell membrane (Rahman et al. 2005). Sudharhsan et al. (2007) also demonstrated the importance of $\mathrm{pH}$ and temperature for the synthesis and secretion of microbial amylases (Sudharhsan et al. 2007).

In this study, RSM was employed to optimize culture conditions for enzyme production using a soybean residue as a carbon source. The best conditions for $\beta$-galactosidase production by the filamentous fungus $A$. niger at the evaluated parameters were initial medium $\mathrm{pH} 7.0$, agitation speed of $120 \mathrm{rpm}$, temperature of $28^{\circ} \mathrm{C}$, and fermentation duration of 7 days. Among the various nutrient sources tested, the minimum medium with $2 \%$ $(\mathrm{w} / \mathrm{v})$ of the soybean residue was sufficient for maximal enzyme production. The medium supplemented with the soybean residue is economically viable, with a good potential for the biotechnological industry. Khayati et al. (2014) has studied beta-galactosidase production from indigenous and inexpensive wastes under SSF conditions using statistical experimental design Methods. Design of experimental methodology using Taguchi orthogonal array was applied to evaluate the influence of five factors (peanut pod concentration, $\mathrm{C} / \mathrm{N}$ ratio, incubation time, type of solid substrate and lactose concentration) on the $\beta$-galactosidase production by Bacillus licheniformis under solid-state fermentation. The results showed that peanut pod concentration, incubation time and lactose (as inducer) were found to be the most effective factor for promoting enzyme production, followed by the $\mathrm{C} / \mathrm{N}$ ratio.

The result obtained regarding the enzymatic activity of $\beta$-galactosidase in this work was higher than or similar the other studies found in the literature involving different culture media and different microorganisms. Meanwhile, Braga et al. (2012) obtained a $\beta$-galactosidase activity of $10.4 \mathrm{U} / \mathrm{mL}$ from Kluyveromyces marxianus grown in a medium containing a rice effluent (Braga et al. 2012_ENREF_38). Nagy et al. (2001) obtained $\beta$-galactosidase activity of $14.31 \mathrm{U} / \mathrm{mL}$ from Penicillium chrysogenum in a fermentation medium containing lactose. Braga et al. (2012) achieved an activity of $10.4 \mathrm{U} /$ $\mathrm{mL}$ expressed by $K$. marxianus in an effluent from rice cultivation. Chuming Nie et al. (2013) were able to produce higher $\beta$-galactosidase activity, 24.5 and $31 \mathrm{U} / \mathrm{mL}$, by means of recombinant lactobacilli systems in Pichia pastoris (Nie et al. 2013).

\section{$\beta$-Galactosidase purification}

Literature data reveal some strategies for purifying $\beta$-galactosidases from filamentous fungi. Some methodologies involve several chromatography steps resulting in multiple yield and purification factor levels. Nagy et al. (2001) purified a fungus $\beta$-galactosidase from a Penicillium chrysogenum strain on an ion exchange column and affinity column. Their study achieved a purification index of 66 and a yield of 8\% (Nagy et al. 2001). O'Connell and Walsh (2008) purified two isoforms of $\beta$-galactosidase from $A$. carbonarius reaching a purification factor of 6 and 3 and a yield of $5 \%$ and $1 \%$ by gel chromatographic techniques with ion exchange and hydrophobic columns (O'Connell and Walsh 2008). Isobe et al. (2013a; b) purified two $\beta$-galactosidase subunits from Teratosphaeria acidotherma reaching a purification factor and yield of 375 and $2.9 \%$, respectively. In that study, the authors used ion exchange chromatography (DEAE), gel filtration, and hydrophobic and affinity columns (Isobe et al. 2013b).

Nonetheless, a smaller number of purification steps are important for reducing the cost and losses of a target compound. In many cases, the costs of these operations can reach $80 \%$ of the total cost of production.

Dimeric $\beta$-galactosidases with similar molecular weight that were observed in this study are consistent with the data reported in the literature for different fungi and bacteria $\beta$-galactosidases. Isobe et al. (2013a; b) found a fungal $\beta$-galactosidase of $140 \mathrm{kDa}$ with two subunits of 86 and $50 \mathrm{kDa}$ (Isobe et al. 2013b). Nagy et al. (2001) reported that the $\beta$-galactosidase from Penicillium chrysogenum is a multimeric enzyme of $\sim 270 \mathrm{kDa}$ composed of $66 \mathrm{kDa}$ monomers (Nagy et al. 2001). Kong et al. (2014) cloned the $\beta$-galactosidase of Thermotoganaphthophila and expressed it in E. coli. The purified recombinant enzyme showed a molecular weight of $70 \mathrm{kDa}$ (Kong et al. 2014). The fungal $\beta$-galactosidase in this work was obtained with few purification steps from a low-cost residue, thus being valuable for the industry from the economic point of view.

\section{$\beta$-Galactosidase characterization}

Our results are in agreement with the literature, where Lima et al. (1982) purified an A. niger $\beta$-galactosidases with an optimum temperature of $65{ }^{\circ} \mathrm{C}$ and optimum $\mathrm{pH}$ of 4.5 (Lima et al. 1982). Generally, $\beta$-galactosidases produced by fungi present optimal $\mathrm{pH}$ in the acidic range and have relatively high optimal temperature (O'Connell and Walsh 2008). Gekas and Lopez-Leiva (1985) reported that an $A$. niger $\beta$-galactosidase was characterized and found to have an optimum $\mathrm{pH}$ between 3.0 and 4.0 and optimum temperature between 55 and $60{ }^{\circ} \mathrm{C}$. A. oryzae $\beta$-galactosidase shows an optimum $\mathrm{pH}$ of 5.0 and optimum temperature between $50{ }^{\circ} \mathrm{C}$ and $55{ }^{\circ} \mathrm{C}$ (Gekas 
and Lopez-Leiva 1985). The isoforms of $\beta$-galactosidase from $A$. carbonarius during submerged fermentation were described by O'Connell and Walsh (2008), showing optimal $\mathrm{pH}$ values of 3.0 and 5.0 and optimum temperatures of $55^{\circ} \mathrm{C}$ and $65{ }^{\circ} \mathrm{C}$ (O'Connell and Walsh 2008). It was observed that in an $A$. niger strain studied by Niu et al (2017) the enzyme produced has an optimum $\mathrm{pH}$ between 4 and 5 and an optimum temperature of $50{ }^{\circ} \mathrm{C}$ that supports the results found for $\beta$-galactosidase studied in this work (Niu et al. 2017). These results for temperature and $\mathrm{pH}$ are similar to other reported in the literature for $\beta$-galactosidases from Aspergillus spp. $\beta$-galactosidase from $A$. lacticoffeatus presented an optimal temperature in the range 50-60, and remained quite active for temperatures between $35{ }^{\circ} \mathrm{Cand} 65{ }^{\circ} \mathrm{C}$. The optimal $\mathrm{pH}$ for this $\beta$-galactosidase was found in the range 3.5-4.5, and the enzymatic activity decreased significantly for higher $\mathrm{pH}$ values (Cardoso et al. 2017). $\beta$-Galactosidase from Aspergillus nidulans was purified and characterized in term of its catalytic properties and stability. It displayed highest catalytic efficiency at $60^{\circ} \mathrm{C}$ after 10.0 min within acidic $\mathrm{pH}$ environment ( $\mathrm{pH}$ 5). The $\beta$-galactosidase exhibited $100 \%$ and $60 \%$ catalytic activity at $40{ }^{\circ} \mathrm{C}$ and $50{ }^{\circ} \mathrm{C}$, respectively even after $120.0 \mathrm{~min}$. The $\beta$-galactosidase activity was remained stable in the presence of $\mathrm{Zn}^{2+}, \mathrm{Ni}^{2+}$, and $\mathrm{Mg}^{2+}$ ions. The activity was also retained in all investigated organic solvents except DMSO at various ionic concentrations. The surfactants Triton X-100 and SDS caused positive impact on the catalytic activity of enzyme at $1.0 \mathrm{mM}$ concentration (Kamran et al. 2019).

Bernal et al (2012) identified a $\beta$-galactosidase produced by Bacillus circulans which lost about $90 \%$ of its activity after $8 \mathrm{~h}$ at $55^{\circ} \mathrm{C}$ (Bernal et al. 2012). Raol et al (2015) identified a $\beta$-galactosidase produced by an Aspergillus species that maintained $50 \%$ of the residual activity for $30 \mathrm{~min}$ at $70{ }^{\circ} \mathrm{C}$, at which temperature the enzyme lost all the catalytic activity in about $5 \mathrm{~h}$. However, for thermostability studies at $50{ }^{\circ} \mathrm{C}$ relative enzymatic activity decreases to about $40 \%$ after $3 \mathrm{~h}$ (Raol et al. 2015).

Regarding the industrial applicability of this enzyme, it is likely that $\beta$-gal is an enzyme as efficient as others already reported in the literature. Shaikh et al. (1999) published for Rhizomucor $\beta$-galactosidase $\mathrm{K}_{\mathrm{m}}$ of $1.32 \mathrm{mM}$ toward the ONPG substrate and $\mathrm{K}_{\mathrm{m}}$ of $50 \mathrm{mM}$ for lactose (Shaikh et al. 1999). O'Connell and Walsh (2008) isolated two $\beta$-galactosidases from $A$. carbonarius where the $\mathrm{K}_{\mathrm{m}}$ values for ONPG were 2.23 and $0.56 \mathrm{mM}$, and for lactose 82.68 and $308.9 \mathrm{mM}$. The $\mathrm{V}_{\max }$ values for the same enzymes were 1.20 and $75 \mathrm{UI} /$ $\mathrm{mL}$ toward ONPG and $146 \mathrm{UI} / \mathrm{mL}$ and $9.3 \mathrm{UI} / \mathrm{mL}$ for lactose (O'Connell and Walsh 2008). O'Connell and
Walsh (2010) reported $\mathrm{K}_{\mathrm{m}}$ of $1.74 \mathrm{mM}$ and $\mathrm{V}_{\max }$ of 137 $\mathrm{UI} / \mathrm{mL}$ for ONPG, and for lactose, $\mathrm{K}_{\mathrm{m}}$ of $48.07 \mathrm{mM}$ and $\mathrm{V}_{\max }$ of $16 \mathrm{UI} / \mathrm{mL}$ in a study on $A$. niger $\beta$-galactosidase (O'Connell and Walsh 2010). It is important to have an enzyme acidic resistant for $\sim 90 \mathrm{~min}$ (the gastric environment of the enzyme remains buffered at acidic $\mathrm{pH}$ for this period), so that it reaches the intestine (lactose hydrolysis site) with its preserved catalytic activity. Most commercial preparations do not fully meet the criteria for an optimal supplement. They require enteric coating to protect the supplemental enzyme from the effects of low gastric $\mathrm{pH}$ and necessitate higher doses to ensure the required hydrolysis. O'Connell and Walsh (2006) tested in vitro whether the products marketed as an enzymatic supplement of $\beta$-galactosidase are compatible with the digestive conditions; they concluded that most of the enzyme preparations were sensitive to gastric acidic $\mathrm{pH}$, thereby retaining only $65 \%$ of the enzymatic activity after exposure to digestive-tract conditions. Still, the researchers cautioned that to ensure the degree of hydrolysis required for a dairy-based meal, the number of capsules ingested would have to be increased over the amount recommended by the manufacturer. In the study by O'Connell and Walsh (2008), when $\beta$-galactosidase of the $A$. carbonarius was subjected to gastric conditions, it retained $70 \%$ of its activity after $2 \mathrm{~h}$ of incubation (O'Connell and Walsh 2008).

Thus, achieving enzymatic stability of $\beta$-galactosidase in vitro against the hostile gastric conditions is relevant both to guarantee optimal hydrolysis of lactose in vivo and to achieve commercially viable $\beta$-galactosidase preparations (coating free).

In addition, the enzyme has physicochemical characteristics and thermal stability and yields gastric simulation test results favorable for its applicability in the pharmaceutical and food industries. Further studies are needed to complement the results obtained in this work. Nevertheless, this present study introduces a filamentous fungus strain from Brazilian Savannah as a good candidate for the production of $\beta$-galactosidase which $t$ may have properties of industrial value.

The fungal $\beta$-galactosidase in this work was obtained with few purification steps from a low-cost residue, thus being valuable for the industry from the economic point of view. Therefore, the continuation of this enzyme characterization is relevant for industrial application.

\section{Acknowledgements}

This work was carried out with the financial support of the Foundation for Research Support of the Federal District (FAPDF), National Counsel of Technological and Scientific Development (CNPq), and University of Brasilia. 


\section{Authors contribution}

RDAM LC SLC POM conceived and designed the experiments; LC; SLC POM DS YMFB MHM wrote the manuscript: MMF POM MHM EXFF drafted and revised the manuscript. All the authors read and approved the final manuscript.

\section{Funding}

This work was carried out with the financial support of the Foundation for Research Support of the Federal District (FAPDF) (Grant no. FAPDF 193.000.042/2011), National Counsel of Technological and Scientific Development (CNPq), and University of Brasilia.

\section{Competing interests}

The authors declare that they have no competing interests.

\section{Author details}

${ }^{1}$ Laboratory of Natural Products, Health Sciences School, Department of Pharmaceutical Sciences, University of Brasília, Brasília, DF CEP 7910-900, Brazil. ${ }^{2}$ Laboratory of Enzymology, Department of Cellular Biology, University of Brasilia, Brasília, DF CEP 70910-900, Brazil.

Received: 8 November 2018 Accepted: 30 May 2019

Published online: 10 June 2019

\section{References}

Bergquist PL, Te'o VJ, Gibbs MD, Cziferszky AC, De Faria FP, Azevedo MO, Nevalainen KH (2002) Production of recombinant bleaching enzymes from thermophilic microorganisms in fungal hosts. Appl Biochem Biotechnol 98(1-9):165-176. https://doi.org/10.1385/abab:98-100:1-9:165

Bernal C, Sierra L, Mesa M (2012) Improvement of thermal stability of $\beta$-galactosidase from Bacillus circulans by multipoint covalent immobilization in hierarchical macro-mesoporous silica. J Mol Catal B Enzym 84:166-172. https://doi.org/10.1016/j.molcatb.2012.05.023

Bradford MM (1976) A rapid and sensitive method for the quantitation of microgram quantities of protein utilizing the principle of protein-dye binding. Anal Biochem 72(1-2):248-254. https://doi.org/10.1016/00032697(76)90527-3

Braga ARC, Gomes PA, Kalil SJ (2012) Formulation of culture medium with agroindustrial waste for $\beta$-galactosidase production from Kluyveromyces marxianus ATCC 16045. Food Bioproc Tech 5(5):1653-1663. https://doi. org/10.1007/s11947-011-0511-0

Cardoso BB, Silvério SC, Abrunhosa L, Teixeira JA, Rodrigues LR (2017) $\beta$-galactosidase from Aspergillus lacticoffeatus: a promising biocatalyst for the synthesis of novel prebiotics. Int J Food Microbiol 257:67-74

de Siqueira FG, de Siqueira EG, Jaramillo PMD, Silveira MHL, Andreaus J, Couto FA, Batista LR, Ferreira Filho EX (2010) The potential of agro-industrial residues for production of holocellulase from filamentous fungi. Int Biodeterior Biodegradation 64(1):20-26. https://doi.org/10.1016/j.ibiod .2009 .10 .002

Embrapa (2016) Embrapa Soja. PUblisher. www.embrapa.br/web/portal/soja/ cultivos/soja1/dados-economicos Accessed 20 Jan 2016

Gekas V, Lopez-Leiva M (1985) Hydrolysis of lactose: a literature review. Process Biochem 20(1):2-12

Hajji M, Rebai A, Gharsallah N, Nasri M (2008) Optimization of alkaline protease production by Aspergillus clavatus ES1 in Mirabilis jalapa tuber powder using statistical experimental design. Appl Microbiol Biotechnol 79(6):915. https://doi.org/10.1007/s00253-008-1508-0

Hu X, Robin S, O'Connell S, Walsh G, Wall JG (2010) Engineering of a fungal $\beta$-galactosidase to remove product inhibition by galactose. Appl Microbiol Biotechnol 87(5):1773-1782

Isobe K, Takahashi N, Chiba S, Yamashita M, Koyama T (2013a) Acidophilic fungus, Teratosphaeria acidotherma AIU BGA-1, produces multiple forms of intracellular $\beta$-galactosidase. J Biosci Bioeng 116(2):171-174. https:// doi.org/10.1016/j.jbiosc.2013.02.018

Isobe K, Yamashita M, Chiba S, Takahashi N, Koyama T (2013b) Characterization of new $\beta$-galactosidase from acidophilic fungus, Teratosphaeria acidotherma AIU BGA-1.J Biosci Bioeng 116(3):293-297. https://doi. org/10.1016/j.jbiosc.2013.03.012
Jegannathan KR, Nielsen PH (2013) Environmental assessment of enzyme use in industrial production-a literature review. J Clean Prod 42:228-240. https://doi.org/10.1016/j.jclepro.2012.11.005

Kamran A, Bibi Z, Aman A, Qader SAU (2019) Purification and catalytic behavior optimization of lactose degrading $\beta$-galactosidase from Aspergillus nidulans. J Food Sci Technol 56(1):167-176

Khayati G, Anvari M, Kazemi S (2014) Peanut pod-an inexpensive substrate for $\beta$-galactosidase production by Bacillus sp. in solid-state fermentation: process evaluation and optimization by Taguchi design of experimental (DOE) methodology. Minerva Biotecnol 26(4):301-307

Kishore D, Kayastha AM (2012) A $\beta$-galactosidase from chick pea (Cicer arietinum) seeds: its purification, biochemical properties and industrial applications. Food Chem 134(2):1113-1122. https://doi.org/10.1016/j. foodchem.2012.03.032

Klein MP, Jong EVd, Révillion JPP (2010) Use of $\beta$-galactosidase in milk sweet: avoiding lactose crystallization. Ciênc Agrotec 34(6):1530-1535. https:// doi.org/10.1590/S1413-70542010000600025

Kong F, Wang Y, Cao S, Gao R, Xie G (2014) Cloning, purification and characterization of a thermostable $\beta$-galactosidase from Thermotoga naphthophila RUK-10. Process Biochem 49(5):775-782. https://doi.org/10.1016/j.procb io.2014.02.008

Leatherbarrow R (1999) Enzfitter Manual, a non-linear curve fitting program for Windows. Biosoft, London, p 1104

Lima CAA, Lima EDPA, Gerald LTS (1982) Obtenção e caracterização da enzima $\beta$-galactosidase de origem fungica. Rev Agropecuária técnica. 3(2):73-80

Liu C, Ruan H, Shen H, Chen Q, Zhou B, Li Y, He G (2007) Optimization of the fermentation medium for alpha-galactosidase production from Aspergillus foetidus ZU-G1 using response surface methodology. J Food Sci. https ://doi.org/10.1111/j.1750-3841.2007.00328.x

Moreira LRdS, Ferreira GV, Santos SST, Ribeiro APS, Siqueira FG, Ferreira Filho EX (2012) The hydrolysis of agro-industrial residues by holocellulose-degrading enzymes. Braz J Microbiol 43(2):498-505. https://doi.org/10.1590/ S1517-83822012000200010

Nagy Z, Kiss T, Szentirmai A, Biró S (2001) ß-Galactosidase of Penicillium chrysogenum: production, purification, and characterization of the enzyme Protein Expr Purif 21(1):24-29. https://doi.org/10.1006/prep.2000.1344

Nie C, Liu B, Zhang Y, Zhao G, Fan X, Ning X, Zhang W (2013) Production and secretion of Lactobacillus crispatus $\beta$-galactosidase in Pichia pastoris. Protein Expr Purif 92(1):88-93. https://doi.org/10.1016/j.pep.2013.08.019

Niu D, Tian X, Mchunu NP, Jia C, Singh S, Liu X, Prior BA, Lu F (2017) Biochemical characterization of three Aspergillus nigerß-galactosidases. Electron J Biotechnol 27:37-43. https://doi.org/10.1016/j.ejbt.2017.03.001

O'Connell S, Walsh G (2006) Physicochemical Characteristics of Commercial Lactases Relevant to Their Application in the Alleviation of Lactose Intolerance. Appl Biochem Biotechnol 134(2):179-192

O'Connell S, Walsh G (2008) Application relevant studies of fungal $\beta$-galactosidases with potential application in the alleviation of lactose intolerance. Appl Biochem Biotechnol 149(2):129-138. https://doi. org/10.1007/s12010-007-8098-7

O'Connell S, Walsh G (2010) A novel acid-stable, acid-active $\beta$-galactosidase potentially suited to the alleviation of lactose intolerance. Appl Microbiol Biotechnol 86(2):517-524. https://doi.org/10.1007/s00253-009-2270-7

Oliveira C, Guimarães PM, Domingues L (2011) Recombinant microbial systems for improved $\beta$-galactosidase production and biotechnological applications. Biotechnol Adv 29(6):600-609. https://doi.org/10.1016/j. biotechadv.2011.03.008

O'Toole DK (1999) Characteristics and use of okara, the soybean residue from soy milk production a review. J Agric Food Chem 47(2):363-371. https:// doi.org/10.1021/jf980754

Panesar PS, Panesar R, Singh RS, Kennedy JF, Kumar H (2006) Microbial production, immobilization and applications of $\beta$-D-galactosidase. J Chem Technol Biotechnol 81(4):530-543. https://doi.org/10.1002/jctb.1453

Patel R, Dodia M, Singh SP (2005) Extracellular alkaline protease from a newly isolated haloalkaliphilic Bacillus sp.: production and optimization. Process Biochem 40(11):3569-3575

Rahman RNZA, Geok LP, Basri M, Salleh AB (2005) Physical factors affecting the production of organic solvent-tolerant protease by Pseudomonas aeruginosa strain K. Bioresour Technol 96(4):429-436. https://doi.org/10.1016/j. biortech.2004.06.012

Raol GG, Raol B, Prajapati VS, Patel KC (2015) Kinetic and thermodynamic characterization of a halotolerant $\beta$-galactosidase produced by halotolerant 
Aspergillus tubingensis GR1. J Basic Microbiol 55(7):879-889. https://doi org/10.1002/jobm.201400747

Rodrigues MI, lemma AF (2005) Planejamento de experimentos e otimização de processos: uma estratégia sequencial de planejamentos

Shaikh S, Khire J, Khan M (1999) Characterization of a thermostable extracel-

lular $\beta$-galactosidase from a thermophilic fungus Rhizomucor sp. Biochim Biophys Acta Gen Subj 1472(1-2):314-322. https://doi.org/10.1016/S0304 $-4165(99) 00138-5$

Silva COG, Ribeiro JAA, Souto AL, Abdelnur PV, Batista LR, Rodrigues KA, Parachin NS, Filho EXF (2018) Sugarcane Bagasse Hydrothermal Pretreatment
Liquors as Suitable Carbon Sources for Hemicellulase Production by Aspergillus niger. BioEnergy Res 11(2):316-329

Sudharhsan S, Senthilkumar S, Ranjith K (2007) Physical and nutritional factors affecting the production of amylase from species of Bacillus isolated from spoiled food waste. Afr J Biotechnol. 6(4):430-435

\section{Publisher's Note}

Springer Nature remains neutral with regard to jurisdictional claims in published maps and institutional affiliations.

\section{Submit your manuscript to a SpringerOpen ${ }^{\circ}$ journal and benefit from:}

- Convenient online submission

- Rigorous peer review

- Open access: articles freely available online

- High visibility within the field

- Retaining the copyright to your article

Submit your next manuscript at $\mathbf{s p r i n g e r o p e n . c o m ~}$ 